\title{
ANTIGENIC RELATIONSHIPS AMONG TYPE-3 FIMBRIAE \\ OF ENTEROBACTERIACEAE REVEALED BY IMMUNOELECTRONMICROSCOPY
}

\author{
D. C. Old and R. A. Adegbola \\ Department of Medical Microbiology, University of Dundee Medical School, Ninewells \\ Hospital, Dundee DD19SY
}

\begin{abstract}
Summary. Antigenic relationships among type-3 fimbriae of 31 strains, representing 19 species and eight genera of Enterobacteriaceae, were investigated by immunoelectronmicroscopy in tests with 17 different type-3 fimbrial antisera. At least nine antigenically distinct groups among type- 3 fimbriae were distinguished. The constituent membership of some groupings did not conform with current views on the taxonomy of Enterobacteriaceae.
\end{abstract}

\section{INTRODUCTION}

The early definitive study of Duguid (1959) established that some strains of Klebsiella and Serratia marcescens formed a haemagglutinin which agglutinated the erythrocytes of different animal species only after the red cells had been treated with tannic acid. That haemagglutinin, which was associated with the presence of thin fimbriae of about 5nm external diameter (Thornley and Horne, 1962), was subsequently designated the $\mathrm{MR} / \mathrm{K}$ (mannose-resistant and klebsiella-like) haemagglutinin by Duguid and Old (1980); the associated thin fimbriae were subsequently classified as type-3 fimbriae (Duguid et al., 1966). Similar MR/K-like haemagglutinins and associated type-3 fimbriae have now been described in many strains of most genera of the tribes Klesielleae and Proteeae (Duguid and Old, 1980; Adegbola and Old, 1982, 1983 and 1985; Old and Adegbola, 1982, 1983 and 1984a; Old et al., 1983). Furthermore, thin, type 3-like fimbriae have been found on a few strains of Salmonella and Yersinia, genera in which type-3 fimbriae are uncommon (Rohde et al., 1975; Aleksic et al., 1976 and 1978; Adegbola et al., 1983a).

Considering their wide distribution throughout the Enterobacteriaceae there is remarkably little information about the antigenic properties of type- 3 fimbriae. Accordingly, the technique of immunoelectronmicroscopy was used in the present comparative study to establish the serological relationships among type- 3 fimbriae of different genera of Enterobacteriaceae.

\section{MATERIALS AND METHODS}

Bacteria. The sources of the 33 strains of Enterobacteriaceae used in this study are given in table I. The identity of each strain was confirmed by conventional methods and in tests with 
TABLE I

Strains of enterobacteria

\begin{tabular}{|c|c|c|c|c|}
\hline Species & $\begin{array}{l}\text { Donor } \\
\text { or source }\end{array}$ & $\begin{array}{l}\text { Strain } \\
\text { no. }\end{array}$ & $\begin{array}{l}\text { Type-3 } \\
\text { fimbriae }\end{array}$ & $\begin{array}{l}\text { Other fimbriae (and } \\
\text { associated haemagglutinins) }\end{array}$ \\
\hline Enterobacter aerogenes & NCIB & 11460 & + & none \\
\hline E. aerogenes & NCTC & 10006 & - & thin fimbriae (MS-HA) \\
\hline E. aerogenes & NCTC & 10336 & - & thin fimbriae (MS-HA) \\
\hline E. gergoviae & BR & & + & none \\
\hline E. gergoviae & $\mathrm{CDC}$ & $558 / 79$ & + & none \\
\hline E. intermedium & CDC & $1163 / 81$ & + & type-1 fimbriae (MS-HA) \\
\hline E. intermedium & $\mathrm{CDC}$ & $9011 / 82$ & + & none \\
\hline Klebsiella oxytoca & JPD & $\mathrm{K} 70 / 1$ & + & none \\
\hline K. oxytoca & JGB & U30 & + & none \\
\hline K. pneumoniae ss. aerogenes & JPD & $\mathrm{K} 4 / 20$ & + & none \\
\hline$K$. pneumoniae ss. aerogenes & JPD & $\mathrm{K} 5 / 1$ & + & none \\
\hline$K$. pneumoniae ss. aerogenes & JPD & K69/1 & + & none \\
\hline Morganella morgani & NCTC & 232 & + & thick fimbriae (MR/P-HA) \\
\hline M. morgani & NCTC & 2815 & + & thick fimbriae (MR/P-HA) \\
\hline Proteus mirabilis & NCTC & 3177 & + & thick fimbriae (MR/P-HA) \\
\hline$P$. mirabilis & NCTC & 10374 & + & thick fimbriae (MR/P-HA) \\
\hline P. vulgaris & NCTC & 10740 & + & none \\
\hline $\begin{array}{l}\text { Providencia alcalifaciens } \\
\text { Prov, rettgeri }\end{array}$ & JLP & T1747 & + & thick fimbriae (non-HA) \\
\hline Prov. stuarti & NCTC & 10318 & $\begin{array}{l}+ \\
+\end{array}$ & $\begin{array}{l}\text { none } \\
\text { thick fimbriae (non-HA) }\end{array}$ \\
\hline Prov. stuarti & BWS & 68027B & + & thick fimbriae (non-HA) \\
\hline Salmonella enteritidis & SA & $45-36 / 71$ & + & type-1 fimbriae (MS-HA) \\
\hline S. enteritidis & SA & $236-36 / 73$ & + & type-1 fimbriae (MS-HA) \\
\hline S. typhimurium & SA & $162-36 / 72$ & + & type-1 fimbriae (MS-HA) \\
\hline S. typhimurium & SA & $221-36 / 73$ & + & type-1 fimbriae (MS-HA) \\
\hline S. manombo SGII & SA & $1427 \mathrm{~K}$ & + & type-1 fimbriae (MS-HA) \\
\hline S. arizonae SGIII & SA & $548-59$ & + & type-1 fimbriae (MS-HA) \\
\hline Serratia marinorubra & NCTC & 3804 & + & $\begin{array}{l}\text { type-1 fimbriae (MS-HA) and } \\
\text { thin fimbriae (MR/P-HA) }\end{array}$ \\
\hline Serr. marinorubra & PADG & $864(2)$ & + & thin fimbriae (MR/P-HA) \\
\hline Serr. plymuthica & NCTC & 8015 & + & none \\
\hline Serr. plymuthica & NCTC & 9493 & + & none \\
\hline Yersinia enterocolitica & GW & IP551 & + & none \\
\hline Y. intermedia & GW & $021 . \mathrm{K}^{+}$ & + & none \\
\hline
\end{tabular}

$\mathrm{CDC}=$ Centers for Disease Control, Atlanta, Georgia, USA; NCIB = National Collection of Industrial Bacteria, Aberdeen; NCTC $=$ National Collection of Type Cultures, Central Public Health Laboratory, London; SA =Dr S. Aleksić, National Salmonella Zentrale Hygienisches Institut, Hamburg, West Germany; JGB = Dr J. G. Barr, Royal Victoria Hosptital, Belfast; JPD = Professor J. P. Duguid, Dundee Medical School, Dundee; PADG =Dr P. A. D. Grimont, Service des Entérobactéries, Unité INSERM, Institute Pasteur, Paris, France; JLP = Dr J. L. Penner, University of Toronto, Ontario, Canada; BR $=\mathrm{Mr}$ B. Reid, API Laboratory Products Ltd, Basingstoke; BWS $=$ Dr B. W. Senior, Dundee Medical School, Dundee; $G W=$ Dr G. Wauters, Universite Catholique de Louvain, Brussels, Belgium.

MS-HA = mannose-sensitive haemagglutinin; MR/P-HA = mannose-resistant and proteus-like haemagglutinin (see Duguid and Old, 1980); non-HA = non-haemagglutinating.

commercial API 20E kits (API Laboratory Products Ltd, Basingstoke, Hampshire). The fimbrial haemagglutinins produced by these strains are also described in table $\mathbf{I}$.

Media and culture methods have been described before (Old and Adegbola, 1982; Adegbola and Old, 1983).

Erythrocytes and haemagglutination tests. The preparation of erythrocyte suspensions, performance of haemagglutination tests and the characterisation of MS-HA, MR/K-HA and MR/P-HA (see Duguid and Old, 1980) have been described in full elsewhere (Adegbola and Old, 1982 and 1983; Old and Adegbola, 1982).

Preparation of fimbrial antisera. Antisera were raised in adult rabbits by the method of Adegbola and Old (1982). Type-3 fimbrial antisera were prepared against MR/K-HA ${ }^{+}$ suspensions of: Enterobacter aerogenes NCIB 11460 and $E$. intermedium CDC 1163/81; Klebsiella oxytoca $\mathrm{K} 70 / 1, K$. pneumoniae ss. aerogenes $\mathrm{K} 5 / 1$ and $\mathrm{K} 69 / 1$; Morganella morgani NCTC 232 and NCTC 2815; Proteus mirabilis NCTC 3177 and NCTC 10374; Providencia 
rettgeri JLP 75, Prov. stuarti NCTC 10318 and BWS 68027B; Serratia plymuthica NCTC 8015 and NCTC 9493; and Yersinia enterocolitica GW IP551.

(i) From each of the 15 crude antisera, homologous $O$ antibodies were removed by repeated absorptions at $37^{\circ} \mathrm{C}$ for $1 \mathrm{~h}$ with dense bacterial suspensions of the vaccine strains that had been grown on nutrient agar at $30^{\circ}$ or $37^{\circ} \mathrm{C}$ for $48 \mathrm{~h}$, boiled at $100^{\circ} \mathrm{C}$ for $1 \mathrm{~h}$ to destroy all flagellar $(H)$ antigens and fimbrial antigens, and washed twice before resuspension in saline to $c .5 \times 10^{11}$ bacteria/ml. Absorption was repeated until a 1 in 20 dilution of antiserum showed no agglutination of a boiled bacterial suspension of the absorbing strain. This procedure yielded antiserum specific for the type-3 fimbriae on strains of Klebsiella that were non-flagellate and produced only type- 3 fimbriae.

(ii) Other antisera were rendered specific for type-3 fimbriae by removing homologous $H$ antibodies with suspensions of the vaccine strains rich in $H$ antigen. Thus, each vaccine strain was grown in several $50-\mathrm{ml}$ volumes of nutrient broth in $1000-\mathrm{ml}$ tissue-culture bottles laid flat on their sides and left at ambient temperature $\left(c .20^{\circ} \mathrm{C}\right)$ for about $18 \mathrm{~h}$. The resultant growth, which is poorly fimbriate at that temperature, was harvested and washed twice before resuspension in saline to give $c .5 \times 10^{11}$ bacteria $/ \mathrm{ml}$. These suspensions, rich in $H$ antigen, were used repeatedly to absorb homologous antiserum at $37^{\circ} \mathrm{C}$ for $1 \mathrm{~h}$, until a 1 in 20 dilution of the serum did not show floccular agglutination of an unboiled flagellate suspension of the absorbing strain. By this procedure, antisera specific for type-3 fimbriae were obtained against type-3 fimbriate strains of E. aerogenes, E. intermedium and Serr. plymuthica.

(iii) For antiserum against the type-3 fimbriae of $Y$. enterocolitica, absorption of $H$ antibodies was similar to that for Enterobacter except that the flagella-rich bacterial suspensions were prepared from a heterologous strain of $Y$. enterocolitica ( $\operatorname{strain} 88$ ) which was flagellate and of the same serotype $(O 10)$ as the vaccine strain, but non-fimbriate. The resultant antiserum did not at a dilution of 1 in 20 agglutinate strain 88; and it did not coat the flagella of the vaccine strain, as shown by electronmicroscopy.

(iv) In addition to type-3 fimbriae, strains of Morganella, Proteus and Providencia often possess other types of fimbriae. These are usually thick, and in Morganella and Proteus (Old and Adegbola, 1982; Adegbola et al., 1983b) they are associated with MR/P-HA (see table I); but in Providencia (Adegbola, 1981; Old and Scott, 1981) they are not associated with any known haemagglutinating activity. Because it was not possible to obtain cultures of Morganella or Proteus that were phenotypically MR/K-HA ${ }^{+}$and MR/P-HA- (Old and Adegbola, 1982), or cultures of Providencia that had lost their non-haemagglutinating thick fimbriae (Adegbola, 1981), fimbrial antisera against these strains contained antibodies against both thick and thin fimbriae. This did not interfere, however, with the assessment of coating of type- 3 fimbriae because observation could be restricted to thin fimbriae.

(v) In addition, fimbrial antisera prepared against S. arizonae SA 548-59 and S. enteritidis SA 45-36/71 were gifts from Dr S. Aleksić.

Electronmicroscopy. The techniques have been described in full elsewhere (Adegbola and Old, 1982; Old and Adegbola, 1982). For preparations of most bacteria, uranyl acetate $0.3 \% \mathrm{w} / \mathrm{v}$ in deionised water ( $p \mathrm{H} \mathrm{4.6)}$ was used (Adegbola and Old, 1982). However, for preparations of cultures of Morganella, Proteus and Providencia, methylamine tungstate ( $p \mathrm{H}$ 6.5), a commercial preparation from EMscope Laboratories Ltd, Ashford, Kent, was used because some fimbriae of some strains in these genera are acid-labile (Abegbola, 1981; Old and Adegbola, 1982).

Immunoelectronmicroscopy. Fimbriate bacteria were also stained by previously described methods (Abegbola and Old, 1982) after interaction with different fimbrial antisera. Degrees of antibody coating of thin fimbriae were recorded on an arbitrary scale from 0 (no coating) to +++ (maximum, strong coating) as described by Adegbola and Old (1982).

\section{RESULTS}

\section{Haemagglutinins and fimbriae}

When cultured in appropriate conditions, e.g., serial broth cultures at $20^{\circ}$ or $30^{\circ} \mathrm{C}$, 29 of the 33 strains listed in table I formed a haemagglutinin (MR/K-HA) active 
against tanned ox-erythrocytes and demonstrable in rocked-tile tests (for details, see Adegbola and Old, 1982 and 1983; Old and Adegbola, 1982, 1983 and 1984a; Old et al., 1983). Another two of the 33 strains, namely S. manombo (subgenus II) and S. arizonae (subgenus III), when cultured similarly, formed an MR/K-like HA which also was active against tanned ox-erythrocytes but required a settling, rather than a rocked-tile, test for its demonstration (Adegbola et al., 1983a).

All 33 strains formed thin, non-channelled fimbriae (putatively type-3 or type 3-like), though E. aerogenes strains NCTC 10006 and NCTC 10336 are known not to form MR/K-HA (Adegbola and Old, 1985).

\section{Immunoelectronmicroscopy}

Haemagglutinating bacteria of the 31 strains that formed MR/K-HA (or MR/K-like HA), and were rich in type- 3 fimbriae, were tested by immunoelectronmicroscopy (IEM) with each of the 17 antisera to type- 3 fimbriae (table II). Several broad areas of serological relatedness were observed.

(i) Fimbrial antisera against five type-3 fimbriate strains ( $K$. oxytoca, $K$. pneumoniae ss. aerogenes ( 2 strains), Y. enterocolitica and $S$. enteritidis) coated strongly the thin fimbriae of homologous and heterologous strains of the same species as the vaccine strains. Furthermore, the thin fimbriae of strains of $E$. gergoviae, $Y$. intermedia and $S$. typhimurium were also coated strongly in tests with these five type- 3 fimbrial antisera.

Type-3 fimbrial antibody coated all the thin fimbriae present on bacteria from $\mathrm{MR} / \mathrm{K}-\mathrm{HA}^{+}$cultures of each of these strains and did so to the same degree $(+++)$ irrespective of whether the haemagglutinating cultures of these strains of Enterobacter, Klebsiella, Salmonella and Yersinia showed MR/K-HA activity alone or together with other kinds of hamagglutinating activities (see table I). The strains so far described, therefore, produced type- 3 fimbriae which seemed to be serologically related to one another, though not necessarily identical.

Type- 3 fimbrial antiserum against the thin fimbriae of the MR/K-HA+ strain of $E$. aerogenes NCIB 11460 strongly coated the thin fimbriae of the homologous vaccine strain as well as the type- 3 fimbriae of $\mathrm{MR} / \mathrm{K}-\mathrm{HA}^{+}$strains of Klebsiella, Salmonella (subgenus I) and Yersinia, just as the type-3 fimbrial antisera of strains of these latter genera coated the thin fimbriae of $E$. aerogenes strain NCIB 11460. Morphologically similar thin fimbriae observed on E. aerogenes strains NCTC 10006 and NCTC 10336, and originally thought by us to belong to the type- 3 group, were not coated by any of the type- 3 fimbrial antisera tested in this series though they were coated by 'thin fimbrial' antisera prepared against strains of $E$. aerogenes other than strain NCIB 11460 (Adegbola and Old, 1985) suggesting heterogeneity among the thin fimbriae of E. aerogenes strains.

(ii) The thin, type 3-like fimbriae on bacteria from haemagglutinating (MR/K-like$-\mathrm{HA}^{+}$) cultures of $S$. manombo and $S$. arizonae (subgenera II and III respectively) were coated by the type 3-like fimbrial antiserum against $S$. arizonae strain 548/59, but not by the other 16 fimbrial antisera tested (table II). Likewise, that $S$. arizonae fimbrial antiserum did not coat the thin fimbriae of any other species examined in this series.

(iii) Type-3 fimbrial antisera prepared against $\mathrm{MR} / \mathrm{K}-\mathrm{HA}^{+}$strains of $E$. intermedium and Serr. plymuthica coated the thin fimbriae present on homologous and 


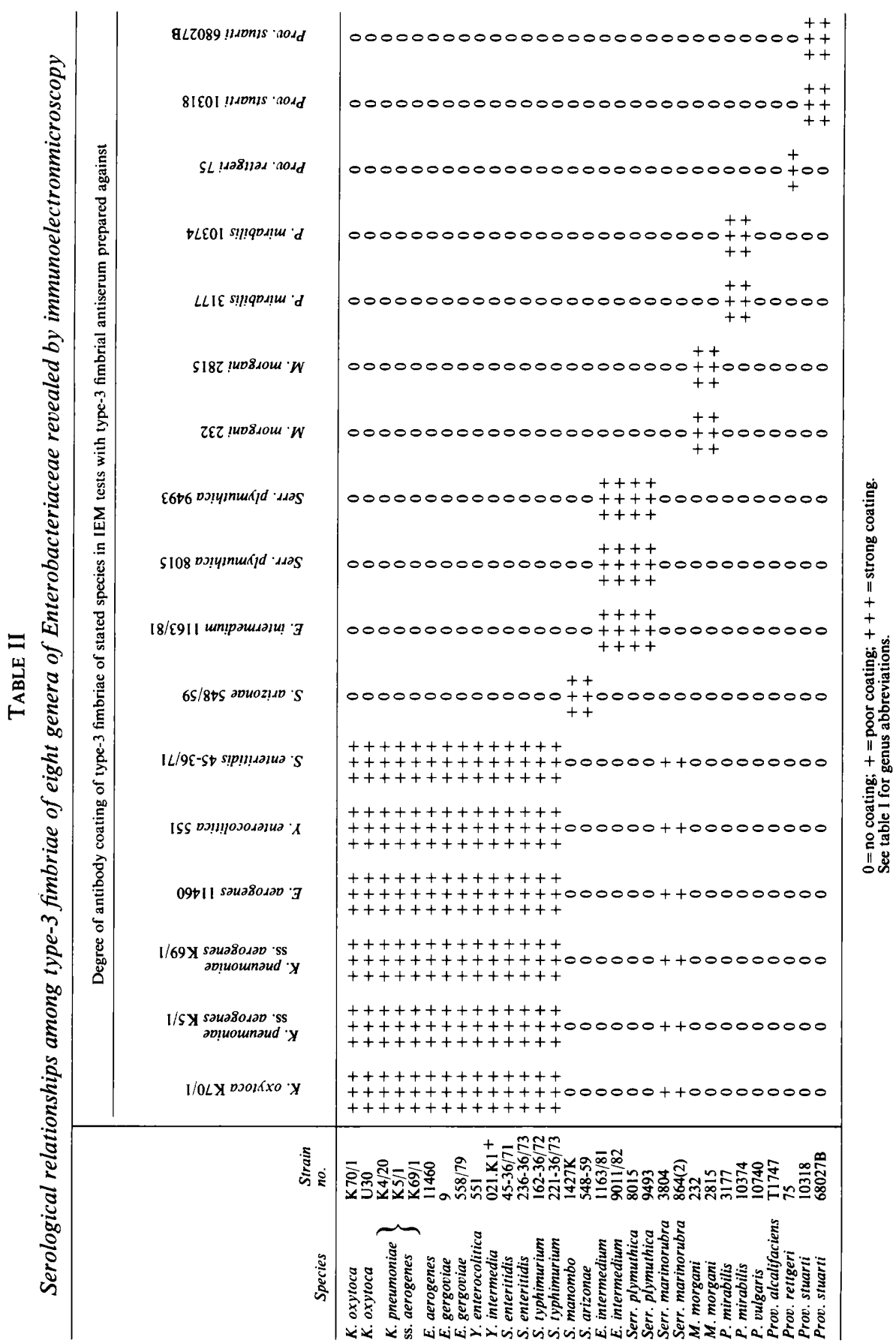


heterologous strains of these two species but did not coat the thin fimbriae of any strain of the other species tested, including $\mathrm{MR} / \mathrm{K}-\mathrm{HA}^{+}$strains of Serr. marinorubra.

(iv) The thin fimbriae present on bacteria from $\mathrm{MR} / \mathrm{K}-\mathrm{HA}^{+}$cultures of Serr. marinorubra were coated, albeit poorly $(+)$, by the type-3 fimbrial antisera raised against strains of E. aerogenes (strain NCIB 11460 only), Klebsiella, Salmonella (subgenus I) and Yersinia, described above in (i).

(v) Each of the type-3 fimbrial antisera prepared against MR/K-HA+ cultures of M. morgani (2 strains), P. mirabilis (2 strains), Prov. rettgeri and Prov. stuarti(2 strains) coated strongly the thin fimbriae of homologous and heterologous strains of the same species only (table II).

(vi) The thin fimbriae of P. vulgaris and Prov. alcalifaciens, against which fimbrial antisera were not prepared, were not coated in tests with any of the 17 type- 3 fimbrial antisera available.

\section{Discussion}

Apart from observations that the type-1 and type-3 fimbriae of Klebsiella are antigenically distinct (Nowotarska and Mulczyk, 1977; Korhonen et al., 1983), there is little information about the antigenic properties of the type- 3 fimbriae of Enterobacteriaceae. In this study we used immunoelectronmicroscopy (IEM), in which type-3 fimbriae were specifically labelled by attachment of type- 3 fimbrial antibody, to assess the degrees of relatedness among type- 3 fimbriae present on strains from eight genera. Previously, IEM has been used successfully to establish serological relationships among different kinds of sex pili (Lawn and Meynell, 1970) and, in intrageneric studies, to identify different kinds of fimbriae present on multi-haemagglutinating strains of different species of Enterobacter, Klebsiella and Serratia (Adegbola and Old, 1982 and 1983; Old and Adegbola, 1983 and 1984a; Old et al., 1983). The data from this and our other IEM studies are summarised in table III from which it is clear that the antigenic relationships are complex and often inconsistent with current taxonomy.

In taxonomic terms, the broadest group ( $a$, table III) comprised the five type- 3 fimbriate species of Klebsiella (Old and Adegbola, 1984) along with representatives of Salmonella, Yersinia and E. aerogenes. The types of fimbriae (and associated haemagglutinins) commonly found on most strains of Salmonella and Yersinia are, respectively, type-1 fimbriae (and MS-HA) and MR/Y fimbriae (and broad-spectrum MR/Y-HA) (Duguid et al., 1966; MacLagan and Old, 1980; Old and Adegbola, 1984b). It has long been known, however, that occasional strains of Salmonella subgenus I possess thin fimbriae, antigenically like those found on strains of $Y$. enterocolitica possessing K1 antigen (Rohde et al., 1975; Aleksić et al., 1976 and 1978; Aleksić and Aleksić, 1979); the knowledge that these fimbriae were also MR/K-HAassociated and antigenically related to those of Klebsiella is more recent (Adegbola $e t$ al., 1983a). Furthermore, the thin fimbriae rarely found on occasional strains of Salmonella of subgenera II and III are unlike the type-3 fimbriae of Salmonella subgenus I in antigenicity (Aleksić et al., 1978), haemagglutinating activity (Adegbola et al., 1983a) and surface hydrophobicity (Dr S. Aleksić, personal communication). We have previously designated these fimbriae as type 3-like (Adegbola et al., 1983a) and their antigenic distinctness is clear.

The classification of the thin fimbriae found on different species of Enterobacter has 
TABLE III

Antigenic groups among type-3 fimbriae of Enterobacteriaceae

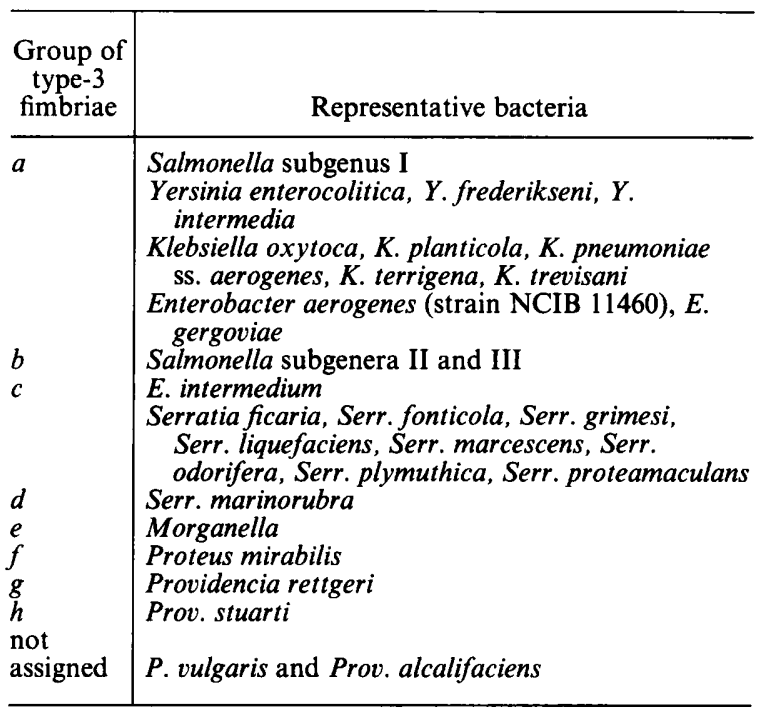

proved troublesome (Adegbola and Old, 1983 and 1985; Old and Adegbola, 1984a). Thus, in antigenic terms the type- 3 fimbriae of $E$. gergoviae are Klebsiella-like and those of E. intermedium are Serratia-like (groups $a$ and $c$, table III). However, whereas the thin fimbriae found on most strains of E. aerogenes (syn. K. mobilis) do not belong to the type-3 class and are associated with MS-HA activity, those on $E$. aerogenes strain NCIB 11460 (the properties of which strain do not identify it definitively as either E. aerogenes or K. pneumoniae ss. aerogenes; Adegbola and Old, 1985) are type 3-like and antigenically similar to those of Klebsiella.

Thus, there is considerable heterogeneity among the thin fimbriae not only of different Enterobacter species but even among those of different strains of the same species. Further evidence of heterogeneity among Enterobacter strains has been obtained from immunodiffusion studies of their glyceraldehyde-3-phosphate dehydrogenases and from principal-components analysis of data on DNA-relatedness; this has led some workers (Izard et al., 1983; Trinel and Leclerc, 1983) to consider unjustified the inclusion, in Enterobacter, of species other than E. cloacae and E. amnigenus. Moreover, these two species form antigenically similar kinds of type-1 fimbriae (Old and Adegbola, 1984a).

The finding that the type-3 fimbriae of Serr. marinorubra belonged to an antigenic group different from that of the other eight species of Serratia is perhaps not surprising, for Serr. marinorubra is poorly related to other Serratia species (Grimont et al., 1977a) and its esterases and proteases are also distinct (Grimont et al., 1977b; Goullet, 1978).

Thus, the type-3 fimbriae of Klebsielleae were distributed through three antigenic groups. None of these was related to the type- 3 fimbriae of Proteeae, which appeared to constitute at least five groups, each species-specific.

This IEM study has established the diversity of antigenic types among the type- 3 
fimbriae of Enterobacteriaceae and the complexity of their inter-relationships. Although it is not yet possible to decide whether the type-3 fimbriae of members within any group are identical or closely related, further experiments with fimbrial antisera absorbed on an intragroup basis may reveal minor antigenic differences among them. In time, receptor studies may also assist analysis of the type- 3 fimbriae, just as in the reclassification of the fimbriae of Escherichia coli that were formerly classed as mannose-resistant and eluting (MRE) on the basis of the common property of their associated MRE haemagglutinins (Duguid, 1964; Duguid and Old, 1980). The classification of the fimbriae associated with tanned erythrocyte haemagglutinins is of similar convenience, and it too may require further assessment as information accumulates. This preliminary IEM study has indicated some points of taxonomic interest that require clarification; it provides a useful basis for future studies.

We thank our colleagues who donated strains and information about them. RAA, an Oyo State scholar on leave from Lagos University Teaching Hospital, Nigeria, thanks the Committee of Vice-Chancellors and Prinicpals (UK) for an Overseas Research Student award.

\section{REFERENCES}

Adegbola R A 1981 Multiple haemagglutinins in enterobacteria. MSc thesis, Dundee University.

Adegbola R A, Old D C 1982 New fimbrial hemagglutinin in Serratia species. Infection and Immunity 38: 306-315.

Adegbola R A, Old D C 1983 Fimbrial haemagglutins in Enterobacter species. Journal of General Microbiology 129:2175-2180.

Adegbola R A, Old D C 1985 Fimbrial and non-fimbrial haemagglutinins in Enterobacter aerogenes. Journal of Medical Microbiology 19:35-43.

Adegbola R A, Old D C, Aleksić S 1983a Rare MR/K-like haemagglutinins (and type 3-like fimbriae) of Salmonella strains. FEMS Microbiology Letters 19:233-238.

Adegbola R A, Old D C, Senior B W 1983b The adhesins and fimbriae of Proteus mirabilis strains associated with high and low affinity for the urinary tract. Journal of Medical Microbiology 16:427-431.

Aleksić S, Aleksić V 1979 Reindarstellung und physikalisch-chemische Analyse des Fimbrienantigens bei zwei verschiedenen Enterobacteriaceae: Salmonella enteritidis und Yersinia enterocolitica. Zentralblatt für Bakteriologie, Parasitenkunde, Infektionskrankheiten und Hygiene I, Abteilung Originale A 243:177-196.

Aleksić S, Rohde R, Aleksić V 1978 Serologische Verwandtschaft der Fimbrienantigene bei Salmonella Subgenus I-Yersinia enterocolitica einerseits und Salmonella Subgenus II-Arizona (=Salmonella Subgenus III) andererseits. Zentralblatt für Bakteriologie, Parasitenkunde, Infektionskrankheiten und Hygiene I, Abteilung Originale A 241:418-426.

Aleksić S, Rohde R, Müller G, Wohlers B 1976 Examination of the envelope antigen K1 in Yersinia enterocolitica which was identified as fimbriae. Zentralblatt für Bakteriologie, Parasitenkunde, Infektionskrankheiten und Hygiene I, Abteilung Originale A 234:513-520.

Duguid J P 1959 Fimbriae and adhesive properties in Klebsiella strains. Journal of General Microbiology 21:271-286.

Duguid J P 1964 Functional anatomy of Escherichia coli with special reference to enteropathogenic E. coli. Revista Latino-americana de Microbiologia 7: supplementos 13-14, 1-16.

Duguid J P, Old D C 1980 Adhesive properties of Enterobacteriaceae. In: Beachey, E H (ed) Bacterial adherence, (Receptors and recognition, series B, vol 6). Chapman and Hall, London, pp 185-217.

Duguid J P, Anderson E S, Campbell I 1966 Fimbriae and adhesive properties in salmonellae. Journal of Pathology and Bacteriology 92:107-138.

Goullet P 1978 Characterization of Serratia marcescens, S. liquefaciens, S. plymuthica and S. 
marinorubra by the electrophoretic patterns of their esterases. Journal of General Microbiology 108:275-281.

Grimont P A D, Grimont F, Dulong de Rosnay H L C 1977a Characterization of Serratia marcescens, $S$. liquefaciens, $S$. plymuthica and $S$. marinorubra by electrophoresis of their proteinases. Journal of General Microbiology 99:301-310.

Grimont P A D, Grimont F, Dulong de Rosnay H L C, Sneath P H A $1977 b$ Taxonomy of the genus Serratia. Journal of General Microbiology 98:39-66.

Izard D, Vincent P, Gavini F, Boniface B, Boniface M, Leclerc H 1983 Application de l'analyse en composantes principales à l'étude des relations génomiques au sein du genre Enterobacter. In: Leclerc, $\mathrm{H}$ (ed) Les bacilles à Gram négatif d'intérêt médical et en santé publique: Taxonomie-identification-applications. Les Colloques de l'-INSERM, Paris. INSERM 114:69-85.

Korhonen T K, Tarkka E, Ranta H, Haahtela K 1983 Type 3 fimbriae of Klebsiella sp.: Molecular characterization and role in bacterial adhesion to plant roots. Journal of Bacteriology 155:860-865.

Lawn A M, Meynell E 1970 Serotypes of sex pili. Journal of Hygiene 68:683-694.

MacLagan R M, Old D C 1980 Haemagglutinins and fimbriae in different serotypes and biotypes of Yersinia enterocolitica. Journal of Applied Bacteriology 49:353-360.

Nowotarska M, Mulczyk M 1977 Serologic relationship of fimbriae among Enterobacteriaceae. Archivum Immunologiae et Therapiae Experimentalis 25:7-16.

Old D C, Adegbola R A 1982 Haemagglutinins and fimbriae of Morganella, Proteus and Providencia. Journal of Medical Microbiology 15:551-564.

Old D C, Adegbola R A 1983 A new mannose-resistant haemagglutinin in Klebsiella. Journal of Applied Bacteriology 55:165-172.

Old D C, Adegbola R A 1984a A comparative immunoelectronmicroscopical study of fimbriae of Enterobacter and Klebsiella. Systematic and Applied Microbiology 5:157-168.

Old D C, Adegbola R A $1984 b$ Relationships among broad-spectrum and narrow-spectrum mannose-resistant haemagglutinins in different Yersinia species. Microbiology and Immunology 28; 1303-1311.

Old D C, Scott S S 1981 Hemagglutinins and fimbriae of Providencia spp. Journal of Bacteriology 146:404-408.

Old D C, Adegbola R A, Scott S S 1983 Multiple fimbrial haemagglutinins in Serratia species. Medical Microbiology and Immunology 172:107-115.

Rohde R, Aleksić S, Müller G, Plavsić S, Aleksić V 1975 Profuse fimbriae conferring O-inagglutinability to several strains of $S$. typhi-murium and $S$. enteritidis isolated from pasta products - cultural, morphological and serological experiments. Zentralblatt für Bakteriologie, Parasitenkunde, Infektionskrankheiten und Hygiene I, Abteilung Originale A, 230:38-50.

Thornley M J, Horne R W 1962 Electron microscopic observations on the structure of fimbriae, with particular reference to Klebsiella strains, by the use of the negative staining technique. Journal of General Microbiology 28:51-56.

Trinel P A, Leclerc H 1983 Étude des relations immunologiques de la glycéraldéhyde-3-phosphate déshydrogénase. In: Leclerc, $\mathrm{H}$ (ed) Les bacilles à Gram négatif d'intérêt médical et en santé publique: Taxonomie-identification-applications. Les colloques de l'INSERM, Paris. INSERM 114:87-97. 